Article

\title{
Impacts of Climate Change and Land Subsidence on Inundation Risk
}

\author{
Ching-Nuo Chen ${ }^{1, *(D)}$ and Samkele S. Tfwala ${ }^{2}$ (D) \\ 1 International Master Program in Soil and Water Engineering, National Pingtung University of Science and \\ Technology, Pingtung 912, Taiwan \\ 2 Department of Soil and Water Conservation, National Chung Hsing University, Taichung 402, Taiwan; \\ samkelet@gmail.com \\ * Correspondence: ginrochen@mail.npust.edu.tw
}

Received: 12 December 2017; Accepted: 1 February 2018; Published: 6 February 2018

\begin{abstract}
In this study, a physiographic drainage-inundation model was used to analyse the impacts of land subsidence and climate change on inundation disaster and risk in a land subsidence area. The results indicated that for land subsidence and land subsidence combined with climate change, inundation area, and volume increased under one- and two-day storms for 2-, 5-, 10-, 25-, 50-, 100-, and 200-year return periods. Moreover, locations that originally had high inundation depth showed even greater inundated areas and volumes in the presence of land subsidence. The inundation phenomenon under the combination of land subsidence and climate change proved to be severe, compared to that of land subsidence alone. Land subsidence increased not only inundation depth but also inundation duration. Given land subsidence and climate change, the average inundation duration for each return period increased. The average flooding duration for each return period post land subsidence was found to be 1.05-1.1 times greater than that preceding it. Under the combination of land subsidence and climate change, the average flooding duration for each return period post land subsidence was about 1.13-1.27 times greater than that before it. Furthermore, by assessing inundation risk with inundation depth index, inundation duration index, and damage index from different land uses, it was found that after land subsidence, inundation risk showed an increase, which was amplified in the presence of land subsidence combined with climate change.
\end{abstract}

Keywords: land subsidence; climate change; physiographic drainage-inundation model; inundation disaster; inundation risk

\section{Introduction}

Owing to an inadequate supply of surface water or economic considerations, people in certain regions of Taiwan have extracted considerable groundwater, causing serious problems, such as land subsidence, seawater encroachment, and soil salinization. According to a Taiwan Water Resources Agency report [1], land subsidence, caused by excessive extraction of groundwater is a concern for approximately one-tenth of Taiwan's plains. In addition, most of the land subsidence areas are located in coastal plains. When such coastal plains experience land subsidence, flooding and seawater encroachment complicate water drainage, leading to severe inundation disasters and jeopardizing national safety.

On average, Taiwan is struck by 3-4 typhoons annually, which lead to seawater intrusion, difficulty in draining flow discharge in rivers, and increased water levels, eventually resulting in flood disasters. According to [2], the maximum inundated depth, area, and time increase with precipitation volume and tidal surge level, leading to severe inundation disasters. Recently, global warming and climate change have intensified, and, according to a report from the Intergovernmental Panel on Climate Change (IPCC) [3], global temperatures are continually rising. Such rising temperatures 
must inevitably lead to abnormal global climate and extreme hydrological phenomena, which will subsequently result in the frequent arrival of natural disasters, such as floods and droughts. Taiwan is situated in a region that is highly vulnerable to climate change. According to statistical data [4], climate change has been increasing the frequency and volume of precipitation and has caused the sea level to rise. For instance, the average rate of sea-level rise for oceans near Taiwan has reached $2.4 \mathrm{~mm} /$ year [5], which is approximately 1.3 times higher than the corresponding rate worldwide $(1.8 \mathrm{~mm} /$ year). In Taiwan's Southwestern coastal areas, the rate has surged to a maximum of $7.89 \mathrm{~mm} /$ year. Therefore, it is apparent that the combined effects of climate change and land subsidence are among the greatest environmental hazards faced by Taiwan, leading to the worst ever inundation and sea-level rise, causing serious harm to the sustainable development of the economy and society [4].

Situations with similar inundation potentials do not necessarily generate the same inundation disaster. The occurrence of a disaster and its degree are typically influenced by the target, time, space of concern, and land utilization conditions. For example, several inundations of identical depth, occurring at different times, locations, and land utilization conditions, cause disasters of different severities. Uitto [6] proposed that the occurrence and severity of a disaster is determined by three basic variables: (1) hazard (natural phenomena such as earthquakes and typhoons), (2) exposure (structures, buildings, humans, and other entities at risk), and (3) vulnerability (propensity to suffer loss). Among these, the concept of disaster risk is the concept that the occurrence of a natural disaster involves a certain degree of uncertainty. As a result, the risk concept is introduced for quantifying disaster loss- and disaster management-related studies [7]. The degree or severity of a disaster depends on the target, the environment exposed to the disaster, and the amount of loss induced by the disaster. Therefore, researchers define disaster risk differently, depending on different research conditions. In the field of natural disaster risk assessment, several assessment equations have been established. Factors such as probability, disaster damage (consequence), vulnerability, and hazard have all been considered by these equations. For example, Hammer [8] defined disaster risk as (1) a combination of probability for the disaster to occur and the damage caused by the disaster (Risk $=$ Probability $\times$ Consequence); (2) a combination of probability for the disaster to occur and the number of entities exposed to the area affected by the disaster (Risk $=$ Probability $\times$ Exposure); (3) Risk $=$ Probability $\times$ Vulnerability; and finally, (4) Risk $=$ Probability $\times$ Exposure $\times$ Vulnerability.

The severity of a flooding disaster is related to the number of people and entities exposed to the disaster as well as the resulting loss. Therefore, how to quantify the damage caused by an inundation disaster is an important factor for planning disaster preventive measures, adjustment strategies, and disaster risk management. Inundation risk assessment is broadly categorized into two types: (1) risk $=$ flood hazard $\times$ fragility (exposure $\times$ social and regional fragility) (e.g., Satu [9-11]) and (2) flood risk $=$ flood occurrence probability $\times$ disaster damage (e.g., [11,12]). For the inundation hazard factor, besides inundation depth, the probability of inundation is considered. Hashimoto, Stedinger and Loucks [7] defined inundation probability by accounting for the duration of inundation, which means that inundation probability is the ratio of inundation duration during a rain incident to the total duration of the rain incident. Vulnerability is categorized according to the land use of the studied area, and is allocated a score based on the monetary value. Finally, the degree of damage is used to determine the vulnerability score.

This study aimed to understand the impacts of land subsidence and climate change on inundation disaster and risk. In addition, an inundation risk assessment method was established. The serious land subsidence area at the Linbian River Basin was selected as the study area. A physiographic inundation-drainage model was applied and combined with a geographic information system (GIS), to simulate the potential inundation, inundated depth, inundated area, inundated volume, and inundation duration under a normal hydrological situation or under a hydrological situation changed by land subsidence and climate change. Further, inundation depth, duration, and loss (vulnerability) were considered, to conduct an inundation risk analysis and to discuss the impacts of land subsidence and climate change on inundation disaster and risk. 


\section{Study Area}

The study area was Linbian River Basin, located in the Southern part of Taiwan. It has a surface area of $336.3 \mathrm{~km}^{2}$ and an approximately $41.3 \mathrm{~km}$ long mainstream. The mainstream has an average slope of $1 / 88$ and an average annual precipitation of approximately $2115 \mathrm{~mm}$. Linbian River, whose map is shown in Figure 1, is one of the major rivers in Pingtung County.

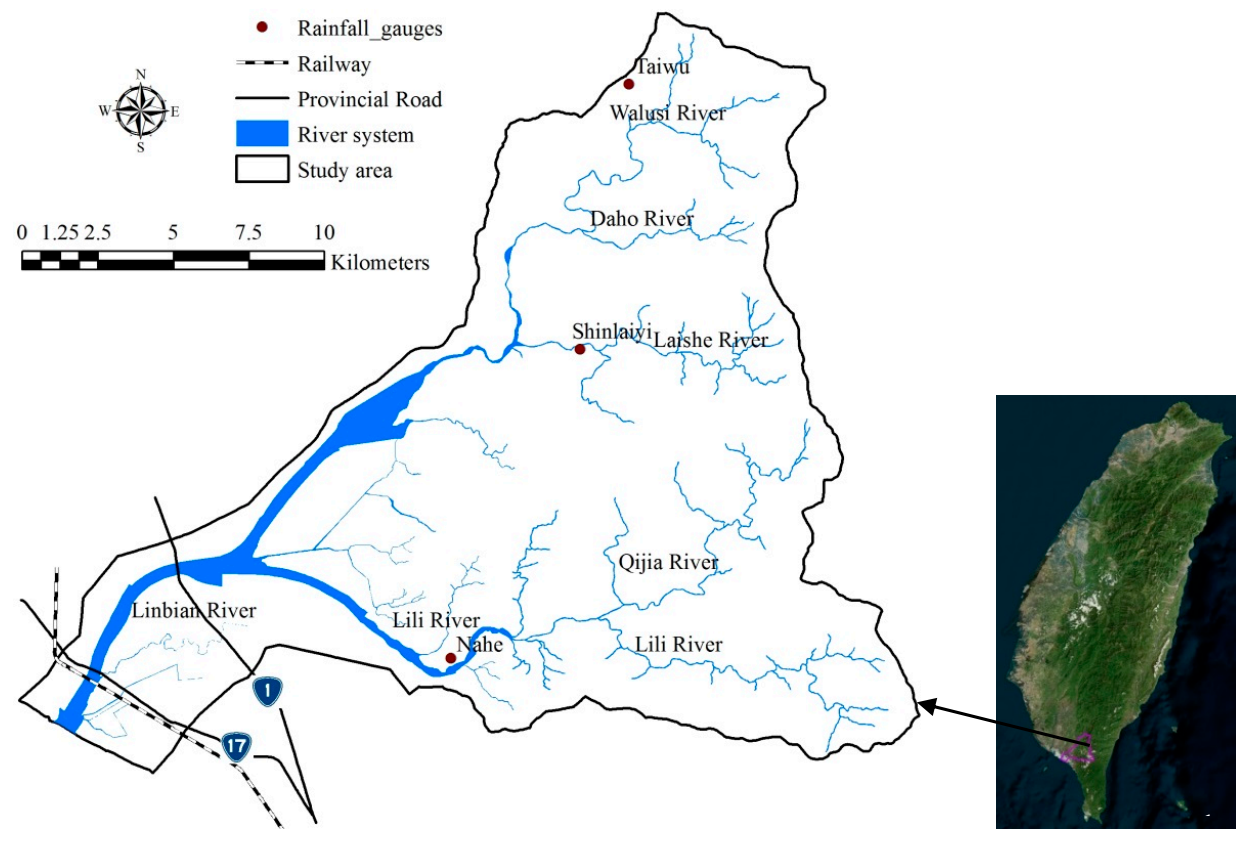

Figure 1. Linbian River Drainage basin.

\section{Method and Data}

Figure 2 shows the flowchart of inundation risk analysis in this paper. The Physiographic Drainage-Inundation model was used to simulate inundation depth, inundation duration, inundation area and volume for various scenarios, to calculate the impact of climate change and land subsidence on inundation risk.

\subsection{Physiographic Drainage-Inundation (PDI) Model}

Based on the topography, landform and river system of the catchment area, the PDI model utilized GIS to partition the catchment area into either land or river computational cells. Hydrological and physiographical data within each cell were obtained through spatial and 3D analyst tools embedded in ESRI ArcMap 10.3. The PDI model then calculated the inundation potential according to the partitioned cell and its attributes. In the migration process of water for the flooding zone, water level change of each cell should then satisfy the continuity equation, as expressed in Equation (1) [13]:

$$
A_{s i} \frac{d h_{i}}{d t}=P_{e i}(t)+\sum_{k} Q_{i, k}\left(h_{i}, h_{k}\right)
$$

where $t$ is time; $A_{s i}$ is the area of the $i$ cell; $h_{i}$ and $h_{k}$ represent water stages of the $i$ and $k$ cells, at time $t$, respectively; and $Q_{i, k}$ denotes the discharge from the $k$ cell into its neighbouring $i$ cell. Discharge is positive when flowing into the $i$ cell from its adjacent $k$ cell and is negative when flowing out of the $i$ cell. $P_{e, i}$ expresses the effective rainfall volume per second in the $i$ cell, which is equal to the effective rainfall per second in the $i$ cell, multiplied by its area. 


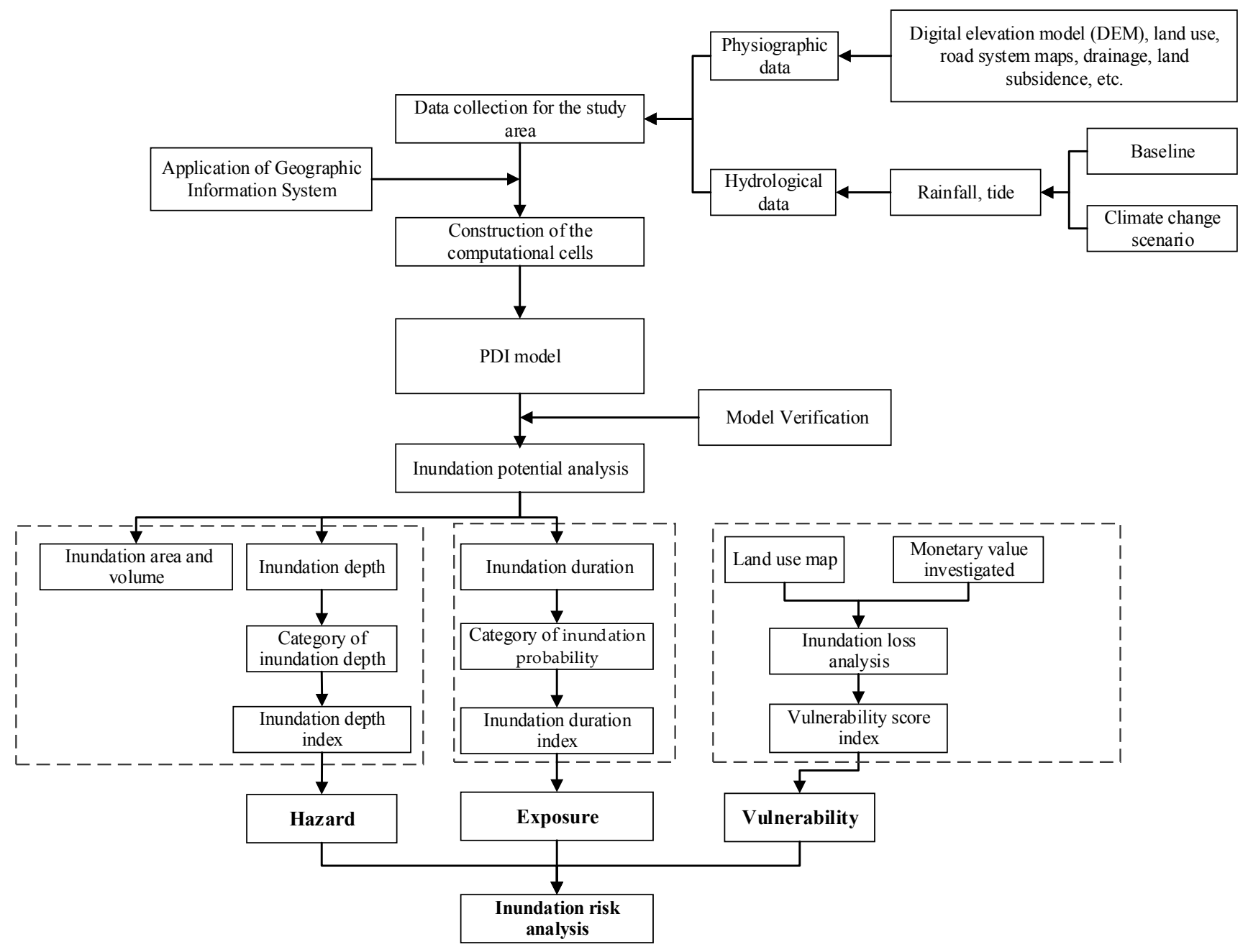

Figure 2. The flowchart of inundation risk analysis. PDI, Physiographic Drainage-Inundation. 
Flow discharge between two adjacent cells is based on the connections between these cells, and can be flow type and box culvert flow type, as described below:

(1) River flow type

If no obvious obstacle exists between neighbouring cells where the flow take place, or there is no flow exchange between neighbouring cells, then it is regarded as overland flow and the average resistance equation (i.e., Manning formula) is used to calculate the flow from a cell to its neighbouring cell. Accordingly, the flow of water from the $k$ cell into its neighbouring $i$ cell is denoted as follows:

$$
Q_{i, k}=\frac{1}{n} A R^{2 / 3} \frac{\left|h_{k}-h_{i}\right|}{\sqrt{\Delta x}}
$$

where $\Delta x$ is the distance between the centre of the $i$ and $k$ cells; $n$ is the Manning roughness coefficient of overland flow between the two neighbouring cells; and $A$ and $R$ are the hydraulic area and radius, respectively, at the border between the two neighbouring cells.

(2) Weir flow type

If the areas are divided by hydraulic or artificial structures, such as roadways, embankments, field ridges, or banks, then the border may be treated as broad-crested weir, and the weir flow formula is used to obtain flow from one cell to its neighbouring cell. Such flow exchange between cells is regarded as the weir flow type. If $h_{k}>h_{i}$, then there are two possible cases-the free weir and the submerged weir-as described below:

a. Free weir $\left(h_{i}-Z_{w}\right)<\frac{2}{3}\left(h_{k}-Z_{w}\right)$

$$
Q_{i, k}=\mu_{f} b \sqrt{2 g}\left(h_{k}-Z_{w}\right)^{1.5}
$$

b. $\quad$ Submerged weir $\left(h_{i}-Z_{w}\right) \geq \frac{2}{3}\left(h_{k}-Z_{w}\right)$

$$
Q_{i, k}=\mu_{S} b \sqrt{2 g}\left(h_{i}-Z_{w}\right)\left(h_{k}-h_{i}\right)^{0.5}
$$

where $Z_{w}$ is the weir height, which is the roadway, bank or ground height; $b$ is the effective width of the weir top, which is equivalent to the intersection length of two adjacent cells; $g$ is gravity; $\mu_{f}$ and $\mu_{s}$ are the weir coefficients of the free and submerged weirs, respectively. $\mu_{f}=0.36-0.57$ and $\mu_{s}=2.6$. In this study, $\mu_{f}=0.45$ and $\mu_{s}=1.17$ are used.

If the flooding area were partitioned into $N$ cells, then there will be $N$ differential equations as Equation (1) with $N$ unknown cell water stages. The correlation between discharge from the $k$ cell into its neighbouring $i$ cell, $Q_{i, k}$, and water stages, $h_{i}$ and $h_{k}$, for cells $i$ and $k$ may be derived from Equations (2)-(4) based on the cell connection type. Using the explicit finite difference method and taking $i$ cell as an example, Equation (1) can be expressed as:

$$
h_{i}^{m+1}=h_{i}^{m}+\frac{\left(\sum_{k} Q_{i, k}^{m}+P_{e i}^{m}\right)}{A_{s i}} \cdot \Delta t
$$

where $h_{i}^{m+1}$ represents the water stage in the $i$ cell at time $m+1 ; h_{i}^{m}$ represents the water stage in the $i$ cell at time $m ; \Delta t$ signifies the time increment between $m$ and $m+1$. The correlation between discharge from the $k$ cell into its neighbouring $i$ cell, $Q_{i, k}$, and water stages, $h_{i}$ and $h_{k}$, for cells, $i$ and $k$, may be derived from Equations (2)-(4). The water stage hydrographs can be obtained from Equation (5) and the corresponding hydrological and physiographic data. 


\subsection{Land Subsidence Depth}

Linbian River Basin is regarded as an area with serious land subsidence (photos in Figure 3). Data were accumulated to quantify the land subsidence of previous years; estimates were calculated based on the land subsidence data collected at the land subsidence inspection points, set up by the Water Resources Agency, Ministry of Economic Planning and Agriculture (MOEA), in the Linbian River catchment area and in nearby areas. The amount of land subsidence accumulated for each inspection point was used together with GIS to construct the accumulated land subsidence numerical diagram shown in Figure 3.

By overlapping the computed cells and the accumulated land subsidence numerical diagram, the amount of land subsidence in each cell can be determined. By subtracting this amount from the original topographical height of each cell, the height of each computed cell after land subsidence can be obtained. This height can then be used to conduct inundation simulation analysis.

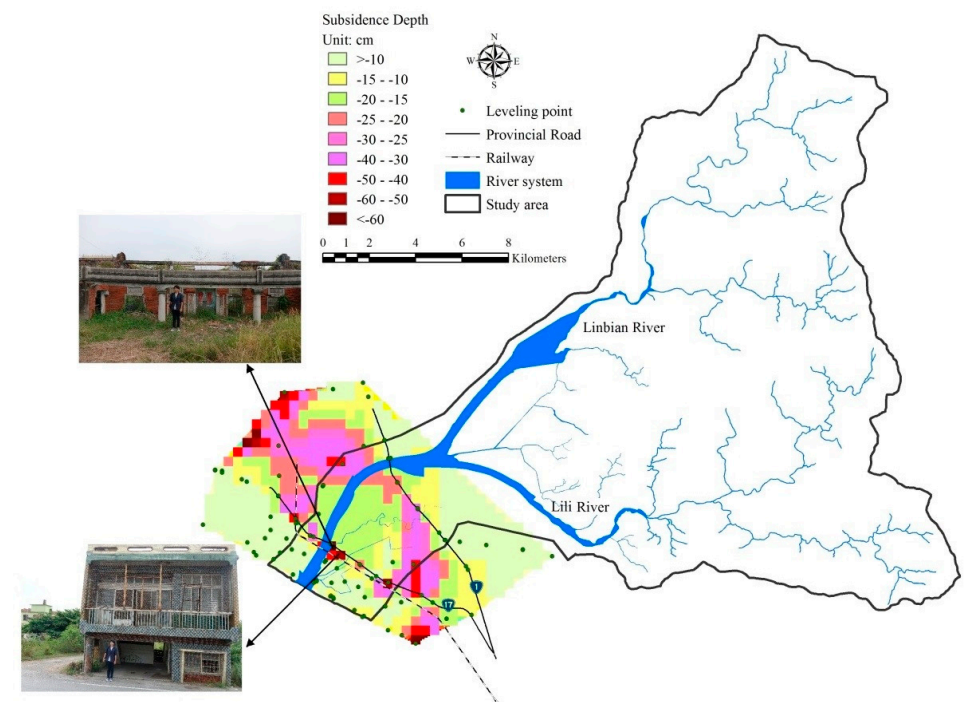

Figure 3. Linbian River land subsidence inspection point distribution and accumulated land subsidence numerical diagram.

\subsection{Inundation Risk Assessment}

In this study, inundation risk assessment was performed using the three variables proposed by [6], which affect the occurrence and degree of a disaster: (1) hazard; (2) exposure; and (3) vulnerability. For instance, the concept of Risk $=$ Hazard $\times$ Exposure $\times$ Vulnerability was applied, where the exposure variable not only accounted for the effect of land utilization but also that of inundation duration. The method used for inundation risk assessment is described as follows:

\section{(1) Inundation depth score index}

The degree of damage caused by flooding depends on inundation depth. According to the results of the inundation depth and monetary loss curve for different land uses, inundation depths induce different degrees of damage - the higher the inundation depth, the larger the inundation damage. For this reason, the inundation risk assessment performed in this study considered the effects of different inundation depths. The inundation depths were categorized into five levels, with each level assigned a score index, as shown in Table 1.

(2) Inundation duration score index

Besides inundation depth, inundation damage is also dependent on flooding durationthe longer the flooding lasts, the greater the damage. Therefore, inundation duration was also 
considered while performing the inundation risk assessment in this study. Here, $D_{c r}$ represents the critical inundation depth in cell $i$ and was used to determine whether cell $i$ was undergoing flooding. For example, $D_{i} \geq D_{c r}$ indicates inundation. Following the guidelines of the Taiwan Water Resources Agency [1], we set $D_{c r}$ as $30 \mathrm{~cm}$. If the rainfall duration is $r_{m}$ hour and the inundation duration is $r_{d}$ hour in cell $i$, the inundation probability is $r_{d} / r_{m}$. Based on the level of flooding probability, an inundation duration score index was assigned, as shown in Table 1.

Table 1. Inundation depth and inundation duration index.

\begin{tabular}{cccc}
\hline Inundation Depth $(\mathbf{m})$ & Inundation Depth Index & Inundation Probability & Inundation Duration Index \\
\hline$<0.3$ & 0 & $<0.01$ & 0 \\
$0.3-0.5$ & 1 & $0.01-0.25$ & 1 \\
$0.5-1.0$ & 2 & $0.25-0.50$ & 2 \\
$1.0-1.5$ & 3 & $0.50-0.75$ & 3 \\
$>1.5$ & 4 & $>0.75$ & 4 \\
\hline
\end{tabular}

(3) Vulnerability score index

The study area covers a wide range of land uses (Figure 4), such as buildings, agricultural land, forest land, and water resources (rivers and drainage); the flooding zone of the study area constitutes low-altitude coastal plains, and the coastal area is mainly used for the construction of populated buildings and agricultural land. Agricultural land includes rice farms, rain-fed crop farms, fruit farms, and fish farms. Table 2 shows the monetary value of each land use according to the investigation conducted by the Sixth River Bureau of the Water Resources Agency [1]. The monetary value of output for various land use per unit area and the consumer price index [14] of Taiwan were used to compute the monetary values presented in Table 2. According to the table, construction land or buildings have the highest monetary values and fishing farms have the highest monetary values among other agricultural activities. Land uses influence not only monetary values, but also the damage induced by disasters, even multiple floods have the same inundation depth. Hence, classification of the investigated area is based on the different land uses and vulnerability score indices, as determined by the monetary values of these land uses. The agricultural land of the investigated area in this study is mostly occupied by fish farms, at which high-value species, such as grouper and shrimp, particularly the Epinephelus lanceolatus (common name: Giant grouper, Brindle bass, and Queensland grouper) are cultivated. For this reason, the vulnerability index of fish farming was separated from that of normal agricultural land, and was assigned according to the monetary values shown in Table 3.

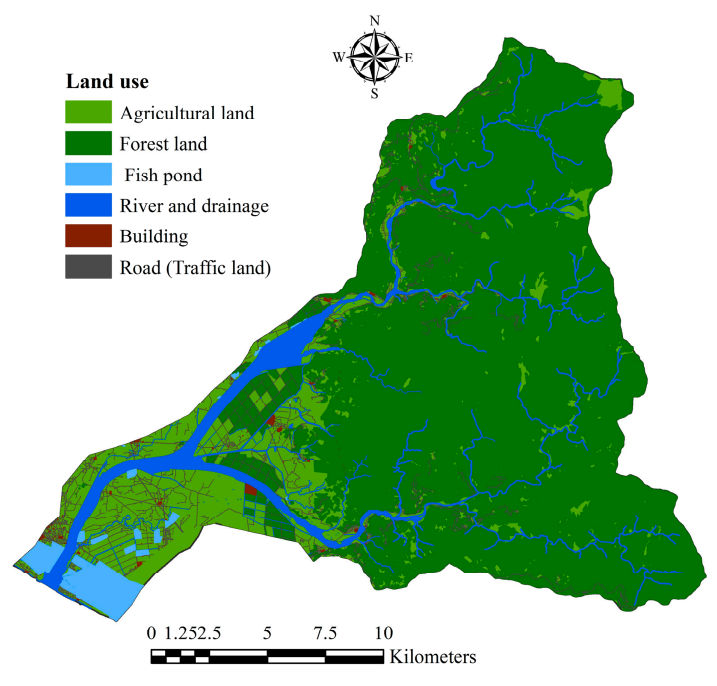

Figure 4. Linbian River basin land use map. 
Table 2. Value of output for various land use per unit area [15].

\begin{tabular}{cc}
\hline Land Use & Monetary Value per Unit Area $\mathbf{( 1 0}^{\mathbf{3}} \mathbf{~ N T D / h a )}$ \\
\hline Fishing farm & $1100(1264)$ \\
Rice farm & $200(230)$ \\
Rain-fed crop farm & $150(172)$ \\
Fruit farm & $800(919)$ \\
Bamboo farm & $560(643)$ \\
Building & $45300(52032)$ \\
\hline
\end{tabular}

() Value of output for land use per unit area multiplied by Consumer Price Index. NTD is New Taiwan Dollar.

Table 3. Vulnerability index for different land uses.

\begin{tabular}{ccccc}
\hline \multirow{2}{*}{ Land Use Classification } & \multirow{2}{*}{ Building } & \multicolumn{3}{c}{ Fishing Farm } \\
\cline { 3 - 5 } & & High Economic-Value Fish Species & Regular Fish Species & \\
\hline Vulnerability index & 4 & 3 & 2 & 1 \\
\hline
\end{tabular}

(4) Inundation risk

Inundation risk represents the possibility of human injury or death and the loss of property due to flooding. Inundation damage is correlated with inundation depth, inundation duration, and land use of the inundated area. Therefore, the inundation risk assessment conducted in this study mainly considered inundation depth, inundation duration, and the inundation loss of land areas with different uses in the flooding area. This index was calculated by multiplying the inundation depth index and inundation probability index (inundation duration) with the inundation disaster loss index, and then dividing it by the product of the highest loss index, as shown below:

$$
\begin{aligned}
\text { Inundation Risk }(\%) & =\frac{\text { Hazard } \times \text { Exposure } \times \text { Vulnerability }}{\text { The product of the highest score index }} \times 100 \\
& =\frac{\text { Depth index } \times \text { Duration index } \times \text { Loss index }}{\text { The product of the highest score index }} \times 100
\end{aligned}
$$

\subsection{Construction of the Computed Cells}

Water runoff from rainfall is influenced by catchment topography, landform, vegetation distribution, and land use. Therefore, to simulate the water runoff process for the investigated catchment area, we partitioned the area into several computed cells based on the aforementioned factors. The complex topography and landforms generated considerable hydrological and physiographical data, and to handle these data ESRI ArcMap 10.3 was used, along with specific spatial analyst, hydrology, 3D analyst, and network analyst extension modules. In addition, object-oriented programming language, flow direction analysis, and formation of river lines were used to automatically partition the catchment area into several sub-catchment areas.

The digital elevation model (DEM) forms the basis of the automatic partitioning of the sub-catchment area. The adopted DEM (Figure 5) had a spatial resolution of $5 \mathrm{~m} \times 5 \mathrm{~m}$ in a regular cell. River width and cells for the automatically partitioned catchment area were assigned based on the recent river measurement data provided by the Linbian River Bureau. To aid in catchment partitioning, the DEM was overlaid with additional maps, such as digitalized soil, land use, and road system maps. Extremely small or narrow cells were combined, and large cells were divided into appropriate cells. Finally, 4290 cells were defined; they are shown in Figure 5. Attributes of each cell served as input to the PDI model. 


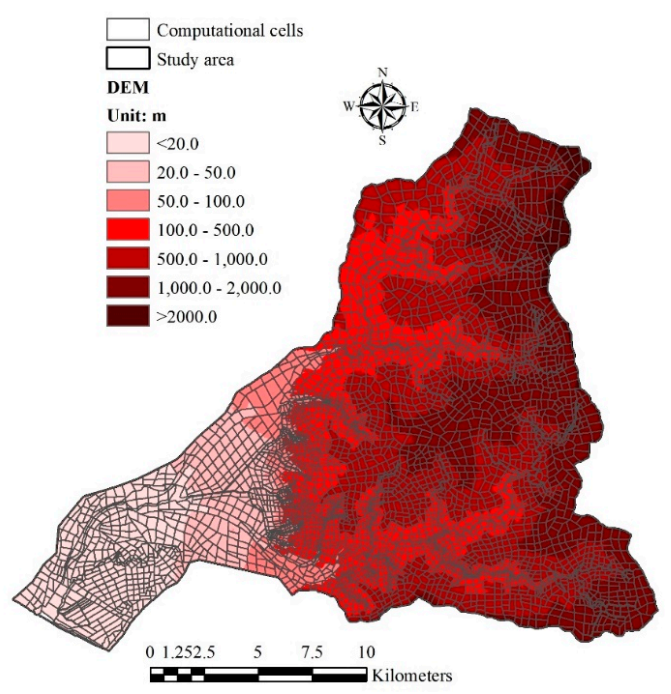

Figure 5. Digital elevation model (DEM) of Linbian River basin.

\subsection{Hydrological Data of Linbian River Basin}

Downscaled monthly precipitation data of climate change scenarios, at a resolution $5 \mathrm{~km} \times 5 \mathrm{~km}$ grid, was provided by the Taiwan Climate Change Projection and Information Platform Project (TCCIP), which is coordinated by the National Science and Technology Centre for Disaster Reduction (NCDR). TCCIP's processing is based on 24 general circulation models (GCMs) [16], reported by the Fourth Assessment Report (AR4) of Intergovernmental Panel on Climate Change (IPCC) [3]. According to the AR4 of IPCC, A2, A1B, and B1 are the major scenarios. Among these, A1B is believed to be the most probable scenario in the future and is expected to receive the most widespread attention. Henceforth, this study adopted the "worst-case scenario" of A1B-S, which is similar to the A1B scenario to evaluate the potential impacts of climate change. The worst-case scenario is mainly determined by adding or subtracting one standard deviation between the estimated values of GCMs from the multi-model ensemble of all GCMs. The future period in this study was set to 2020-2039 and the baseline period set to 1980-1999. The precipitation data of baseline and A1B-S for one and two-day storms under various return periods are shown in Table 4.

Table 4. Precipitation data of baseline and scenario A1B-S for one- and two-day storms under various return periods.

\begin{tabular}{cccccccc}
\hline \multirow{2}{*}{ Return Period (Year) } & \multicolumn{3}{c}{ Baseline } & & \multicolumn{3}{c}{ A1B-S } \\
\cline { 3 - 7 } & & Taiwu & Shinlaiyi & Nahe & Taiwu & Shinlaiyi & Nahe \\
\hline \multirow{2}{*}{2} & one-day & 412.3 & 326.2 & 249.2 & 455.3 & 364.2 & 254.2 \\
& two-day & 643.5 & 534.4 & 387.3 & 694.5 & 572.4 & 411.3 \\
\hline \multirow{2}{*}{5} & one-day & 563.4 & 430.3 & 319.2 & 641.4 & 486.3 & 334.2 \\
& two-day & 856.7 & 690.6 & 501.4 & 967.7 & 765.5 & 538.4 \\
\hline \multirow{2}{*}{10} & one-day & 661.4 & 496.3 & 360.2 & 783.5 & 576.4 & 394.3 \\
& two-day & 988.7 & 786.6 & 574.4 & 1172.9 & 910.7 & 633.5 \\
\hline \multirow{2}{*}{25} & one-day & 783.5 & 576.4 & 408.3 & 985.6 & 699.4 & 480.3 \\
& two-day & 1146.8 & 898.7 & 663.4 & 1462.1 & 1116.9 & 767.6 \\
\hline \multirow{2}{*}{50} & one-day & 871.5 & 632.4 & 441.3 & 1153.7 & 798.5 & 551.3 \\
& two-day & 1258.9 & 975.8 & 727.5 & 1699.3 & 1286.0 & 876.6 \\
\hline \multirow{2}{*}{100} & one-day & 957.6 & 687.4 & 473.3 & 1338.8 & 904.6 & 628.4 \\
& two-day & 1366.0 & 1046.8 & 788.6 & 1957.5 & 1471.1 & 995.7 \\
\hline \multirow{2}{*}{200} & one-day & 1042.6 & 741.5 & 503.3 & 1541.9 & 1018.6 & 714.5 \\
& two-day & 1470.1 & 1114.8 & 848.7 & 2238.7 & 1673.3 & 1125.9 \\
\hline \multirow{2}{*}{5} & & & & & & & \\
& & & & & & & \\
\end{tabular}


The downstream flooding phenomenon is closely related to tidal surge levels. Therefore, in this study, the tidal levels at the Dong Gang Tidal Monitoring Station in 2011 (measured by Tainan Hydraulic Laboratory, National Cheng Kung University) and the tidal levels near Linbian River were considered in the tidal level analysis. These data were also used to determine the downstream boundary conditions in our simulations. The existing tidal level and the increased sea level were used to determine the tidal levels in the climate change scenario.

\section{Results and Discussion}

\subsection{Model Verification}

Typhoon Morakot (2009), which caused severe flooding disaster, was selected to validate the PDI model. We simulated flooding for Typhoon Morakot, from 6 to 10 August 2009, for a total of $120 \mathrm{~h}$. Precipitation data were collected from three rainfall stations, and Thiessen's polygon method was used to partition the control area of each rainfall monitoring station, to serve as an upstream boundary input for the PDI model. The downstream boundary conditions for the simulation were based on data from the Dong Gang Tidal Level Monitoring Station.

The investigated and simulated inundation areas for Typhoon Morakot are shown in Figure 6. The maximum possible inundation depth and inundation area simulated by the PDI model agreed well with the inundation determined on-site.

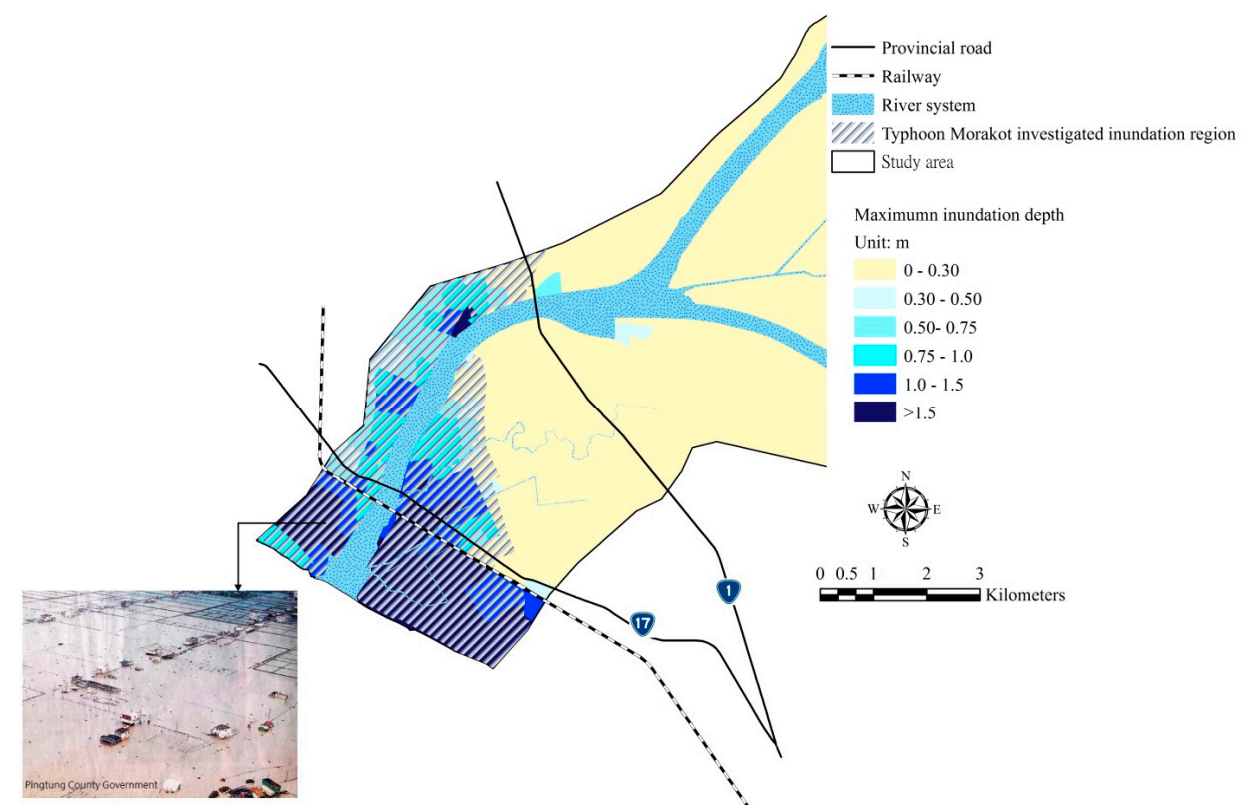

Figure 6. Investigated and simulated inundation depth for Typhoon Morakot.

\subsection{Inundation Disaster Analysis}

To understand the effects of land subsidence and climate change on inundation disaster in the land subsidence area, the PDI model was adopted to simulate the impact of land subsidence and land subsidence combined with climate change on the inundation disaster with rainfall durations of $24 \mathrm{~h}$ and $48 \mathrm{~h}$, under the hydrological condition of normal (baseline) and climate change (A1B-S) scenarios, for the return periods of 2, 5, 25, 50, 100, and 200 years. One- and two-day storms for the 5- and 50-year return periods were selected to demonstrate the increase in inundation depth and distribution after land subsidence and in land subsidence area, under the impact of climate change, as shown in Figures 7-10. Furthermore, the percentages of inundation area and volume increase under different inundation depths in land subsidence and climate change with land subsidence areas are listed in Tables 5-8. 
Figures 7-10 and Tables 5-8 indicate that under the influence of land subsidence and land subsidence combined with climate change, the percentage of inundation area and volume with oneand two-day storms, for different inundation depths in each return period, may increase or decrease. Nevertheless, the overall results showed greater percentages of increase for inundation area and volume. Furthermore, the places with greater inundation depths originally tended to show increased inundation areas and volumes after land subsidence.

Table 5. Percentage of inundation area increase for one-day storm under different return periods and scenarios.

\begin{tabular}{|c|c|c|c|c|c|}
\hline \multirow{2}{*}{ Return Period (Year) } & \multirow{2}{*}{ Scenario } & \multicolumn{4}{|c|}{ Inundation Depth (m) } \\
\hline & & $0.3-0.5$ & $0.5-1.0$ & $1.0-1.5$ & $>1.5$ \\
\hline \multirow[t]{2}{*}{2} & $\begin{array}{l}\text { Subsidence } \\
\% \text { Change }\end{array}$ & 14.84 & 9.57 & 15.27 & 38.31 \\
\hline & $\begin{array}{c}\text { Subsidence + A1B-S } \\
\% \text { Change }\end{array}$ & -4.9 & 34.79 & -3.63 & 67.01 \\
\hline \multirow[t]{2}{*}{5} & $\begin{array}{l}\text { Subsidence } \\
\% \text { Change }\end{array}$ & -15.69 & 4.10 & 39.51 & 21.21 \\
\hline & $\begin{array}{c}\text { Subsidence + A1B-S } \\
\% \text { Change }\end{array}$ & -22.01 & 3.53 & 68.55 & 32.53 \\
\hline \multirow[t]{2}{*}{10} & $\begin{array}{l}\text { Subsidence } \\
\% \text { Change }\end{array}$ & -19.24 & 1.34 & 18.23 & 21.34 \\
\hline & $\begin{array}{l}\text { Subsidence + A1B-S } \\
\% \text { Change }\end{array}$ & -64.65 & 3.82 & 69.58 & 36.44 \\
\hline \multirow[t]{2}{*}{25} & $\begin{array}{l}\text { Subsidence } \\
\% \text { Change }\end{array}$ & -48.21 & 1.21 & 26.97 & 14.93 \\
\hline & $\begin{array}{c}\text { Subsidence + A1B-S } \\
\% \text { Change }\end{array}$ & -50.40 & -19.15 & 33.35 & 85.16 \\
\hline \multirow[t]{2}{*}{50} & $\begin{array}{l}\text { Subsidence } \\
\% \text { Change }\end{array}$ & -52.33 & 0.20 & 12.60 & 25.41 \\
\hline & $\begin{array}{c}\text { Subsidence + A1B-S } \\
\% \text { Change }\end{array}$ & -46.23 & -23.63 & 14.87 & 97.49 \\
\hline \multirow[t]{2}{*}{100} & $\begin{array}{l}\text { Subsidence } \\
\% \text { Change }\end{array}$ & -50.55 & -2.47 & 25.82 & 15.33 \\
\hline & $\begin{array}{c}\text { Subsidence + A1B-S } \\
\% \text { Change }\end{array}$ & -31.53 & -14.20 & 10.58 & 88.47 \\
\hline \multirow[t]{2}{*}{200} & $\begin{array}{l}\text { Subsidence } \\
\% \text { Change }\end{array}$ & -45.63 & -5.98 & 23.45 & 9.54 \\
\hline & $\begin{array}{c}\text { Subsidence + A1B-S } \\
\% \text { Change }\end{array}$ & 86.78 & -13.49 & 16.35 & 66.15 \\
\hline
\end{tabular}

Positive values indicate an increasing trend; negative values indicate a decreasing trend.

Table 6. Percentage of inundation volume increase for one-day storm under different return periods and scenarios.

\begin{tabular}{cccccc}
\hline \multirow{2}{*}{ Return Period (Year) } & Scenario & \multicolumn{3}{c}{ Inundation Depth (m) } \\
\cline { 2 - 5 } 2 & $\begin{array}{c}\text { Subsidence } \\
\text { \% Change }\end{array}$ & 12.97 & 16.96 & 9.91 & 36.07 \\
\hline & $\begin{array}{c}\text { Subsidence + A1B-S } \\
\text { \% Change }\end{array}$ & -10.99 & 45.48 & -10.32 & 60.33 \\
\hline 5 & $\begin{array}{c}\text { Subsidence } \\
\text { \% Change }\end{array}$ & -14.97 & 4.03 & 36.67 & 20.95 \\
\cline { 2 - 6 } & $\begin{array}{c}\text { Subsidence + A1B-S } \\
\text { \% Change }\end{array}$ & -16.22 & 6.03 & 68.28 & 33.77 \\
\hline
\end{tabular}


Table 6. Cont.

\begin{tabular}{|c|c|c|c|c|c|}
\hline \multirow{2}{*}{ Return Period (Year) } & \multirow{2}{*}{ Scenario } & \multicolumn{4}{|c|}{ Inundation Depth (m) } \\
\hline & & $0.3-0.5$ & $0.5-1.0$ & $1.0-1.5$ & $>1.5$ \\
\hline \multirow[t]{2}{*}{10} & $\begin{array}{l}\text { Subsidence } \\
\% \text { Change }\end{array}$ & -12.68 & 4.17 & 18.36 & 20.00 \\
\hline & $\begin{array}{l}\text { Subsidence + A1B-S } \\
\% \text { Change }\end{array}$ & -63.07 & 3.17 & 74.01 & 38.37 \\
\hline \multirow[t]{2}{*}{25} & $\begin{array}{l}\text { Subsidence } \\
\% \text { Change }\end{array}$ & -48.09 & -0.06 & 25.67 & 14.52 \\
\hline & $\begin{array}{l}\text { Subsidence + A1B-S } \\
\% \text { Change }\end{array}$ & -50.91 & -17.39 & 32.13 & 79.77 \\
\hline \multirow[t]{2}{*}{50} & $\begin{array}{l}\text { Subsidence } \\
\% \text { Change }\end{array}$ & -53.33 & -1.43 & 8.42 & 21.99 \\
\hline & $\begin{array}{l}\text { Subsidence + A1B-S } \\
\% \text { Change }\end{array}$ & -47.08 & -24.33 & 10.81 & 97.81 \\
\hline \multirow[t]{2}{*}{100} & $\begin{array}{l}\text { Subsidence } \\
\% \text { Change }\end{array}$ & -54.68 & -6.59 & 21.99 & 14.22 \\
\hline & $\begin{array}{l}\text { Subsidence + A1B-S } \\
\% \text { Change }\end{array}$ & -42.61 & -19.14 & 7.88 & 98.35 \\
\hline \multirow[t]{2}{*}{200} & $\begin{array}{l}\text { Subsidence } \\
\% \text { Change }\end{array}$ & -48.43 & -6.97 & 22.86 & 9.67 \\
\hline & $\begin{array}{l}\text { Subsidence + A1BS1 } \\
\% \text { Change }\end{array}$ & 61.37 & -11.64 & 17.35 & 82.51 \\
\hline
\end{tabular}

Positive values indicate an increasing trend; negative values indicate a decreasing trend.

Table 7. Percentage of inundation area increase for two-day storm under different return periods and scenarios.

\begin{tabular}{|c|c|c|c|c|c|}
\hline \multirow{2}{*}{ Return Period (Year) } & \multirow{2}{*}{ Scenario } & \multicolumn{4}{|c|}{ Inundation Depth (m) } \\
\hline & & $0.3-0.5$ & $0.5-1.0$ & $1.0-1.5$ & $>1.5$ \\
\hline \multirow[t]{2}{*}{2} & $\begin{array}{l}\text { Subsidence } \\
\% \text { Change }\end{array}$ & 15.31 & 17.44 & -21.31 & 38.21 \\
\hline & $\begin{array}{c}\text { Subsidence + A1B-S } \\
\% \text { Change }\end{array}$ & 8.97 & 29.68 & -8.70 & 38.21 \\
\hline \multirow[t]{2}{*}{5} & $\begin{array}{l}\text { Subsidence } \\
\% \text { Change }\end{array}$ & 4.57 & 1.54 & 34.92 & 24.76 \\
\hline & $\begin{array}{c}\text { Subsidence + A1B-S } \\
\% \text { Change }\end{array}$ & 13.40 & 7.46 & 37.84 & 32.50 \\
\hline \multirow[t]{2}{*}{10} & $\begin{array}{l}\text { Subsidence } \\
\% \text { Change }\end{array}$ & -13.29 & -0.31 & 24.73 & 15.59 \\
\hline & $\begin{array}{c}\text { Subsidence + A1B-S } \\
\% \text { Change }\end{array}$ & -35.53 & 3.02 & 46.44 & 40.34 \\
\hline \multirow[t]{2}{*}{25} & $\begin{array}{l}\text { Subsidence } \\
\% \text { Change }\end{array}$ & -26.00 & 13.03 & -0.84 & 24.93 \\
\hline & $\begin{array}{c}\text { Subsidence + A1B-S } \\
\% \text { Change }\end{array}$ & -61.01 & 6.18 & 14.61 & 82.30 \\
\hline \multirow[t]{2}{*}{50} & $\begin{array}{l}\text { Subsidence } \\
\% \text { Change }\end{array}$ & -39.96 & -1.64 & -3.09 & 46.01 \\
\hline & $\begin{array}{c}\text { Subsidence + A1B-S } \\
\% \text { Change }\end{array}$ & -46.33 & -22.06 & 5.93 & 122.67 \\
\hline \multirow[t]{2}{*}{100} & $\begin{array}{l}\text { Subsidence } \\
\% \text { Change }\end{array}$ & -55.81 & 4.03 & 11.83 & 18.62 \\
\hline & $\begin{array}{c}\text { Subsidence + A1B-S } \\
\% \text { Change }\end{array}$ & -52.09 & -27.08 & -0.21 & 103.78 \\
\hline \multirow[t]{2}{*}{200} & $\begin{array}{l}\text { Subsidence } \\
\% \text { Change }\end{array}$ & -58.35 & 3.99 & 22.28 & 9.20 \\
\hline & $\begin{array}{c}\text { Subsidence + A1B-S } \\
\% \text { Change }\end{array}$ & -13.74 & -26.16 & 2.47 & 88.91 \\
\hline
\end{tabular}

Positive values indicate an increasing trend; negative values indicate a decreasing trend. 
Table 8. Percentage of inundation volume increase for two-day storm under different return periods and scenarios.

\begin{tabular}{|c|c|c|c|c|c|}
\hline \multirow{2}{*}{ Return Period (Year) } & \multirow{2}{*}{ Scenario } & \multicolumn{4}{|c|}{ Inundation Depth (m) } \\
\hline & & $0.3-0.5$ & $0.5-1.0$ & $1.0-1.5$ & $>1.5$ \\
\hline \multirow[t]{2}{*}{2} & $\begin{array}{l}\text { Subsidence } \\
\% \text { Change }\end{array}$ & 18.34 & 30.25 & -22.51 & 34.96 \\
\hline & $\begin{array}{c}\text { Subsidence + A1B-S } \\
\% \text { Change }\end{array}$ & 6.86 & 42.85 & -10.39 & 37.02 \\
\hline \multirow[t]{2}{*}{5} & $\begin{array}{l}\text { Subsidence } \\
\% \text { Change }\end{array}$ & 1.75 & 2.85 & 30.46 & 23.58 \\
\hline & $\begin{array}{c}\text { Subsidence + A1B-S } \\
\% \text { Change }\end{array}$ & 14.34 & 14.46 & 37.79 & 32.98 \\
\hline \multirow[t]{2}{*}{10} & $\begin{array}{l}\text { Subsidence } \\
\% \text { Change }\end{array}$ & -4.92 & 3.29 & 25.90 & 16.14 \\
\hline & $\begin{array}{c}\text { Subsidence + A1B-S } \\
\% \text { Change }\end{array}$ & -26.34 & 6.35 & 49.82 & 40.31 \\
\hline \multirow[t]{2}{*}{25} & $\begin{array}{l}\text { Subsidence } \\
\% \text { Change }\end{array}$ & -23.05 & 17.54 & 0.31 & 21.50 \\
\hline & $\begin{array}{c}\text { Subsidence + A1B-S } \\
\% \text { Change }\end{array}$ & -61.50 & 8.97 & 17.73 & 75.86 \\
\hline \multirow[t]{2}{*}{50} & $\begin{array}{l}\text { Subsidence } \\
\% \text { Change }\end{array}$ & -33.49 & -1.53 & -8.52 & 35.29 \\
\hline & $\begin{array}{c}\text { Subsidence + A1B-S } \\
\% \text { Change }\end{array}$ & -48.27 & -20.02 & 0.94 & 112.88 \\
\hline \multirow[t]{2}{*}{100} & $\begin{array}{l}\text { Subsidence } \\
\% \text { Change }\end{array}$ & -54.68 & 2.55 & 9.01 & 16.62 \\
\hline & $\begin{array}{c}\text { Subsidence + A1B-S } \\
\% \text { Change }\end{array}$ & -47.92 & -24.98 & -3.73 & 110.41 \\
\hline \multirow[t]{2}{*}{200} & $\begin{array}{l}\text { Subsidence } \\
\% \text { Change }\end{array}$ & -59.13 & 2.35 & 20.59 & 9.33 \\
\hline & $\begin{array}{c}\text { Subsidence + A1B-S } \\
\% \text { Change }\end{array}$ & -16.54 & -25.13 & -2.35 & 100.86 \\
\hline
\end{tabular}

Positive values indicate an increasing trend; negative values indicate a decreasing trend.

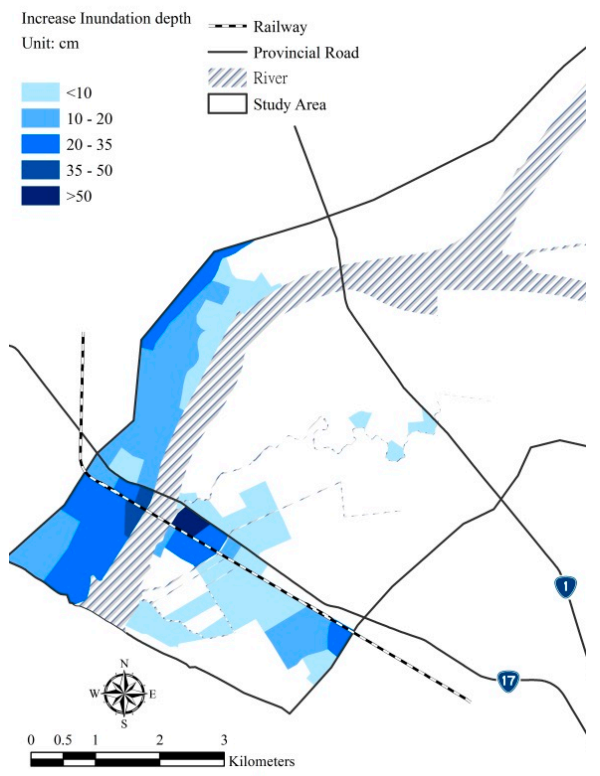

(a)

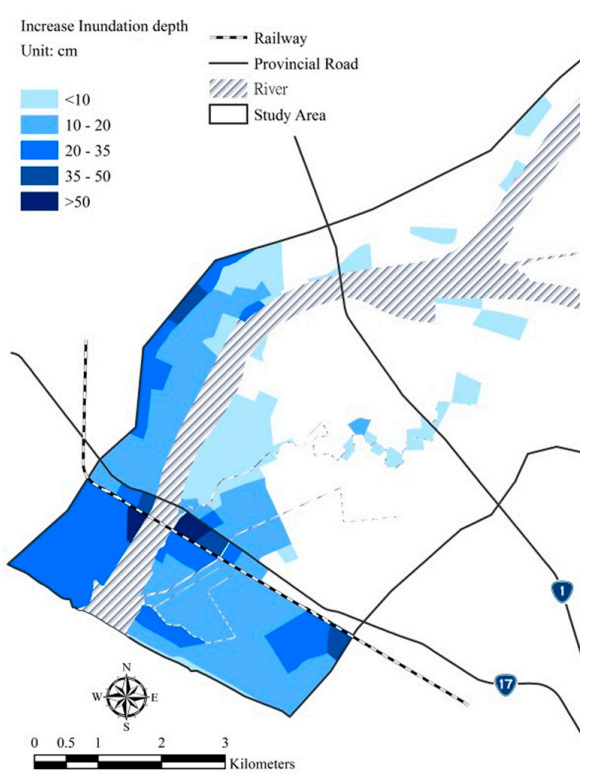

(b)

Figure 7. (a) Spatial distribution of inundation depth increase after land subsidence for a one-day storm under a 5-year return period; (b) Spatial distribution of inundation depth increase after land subsidence combined with climate change for a one-day storm under a 5-year return period. 


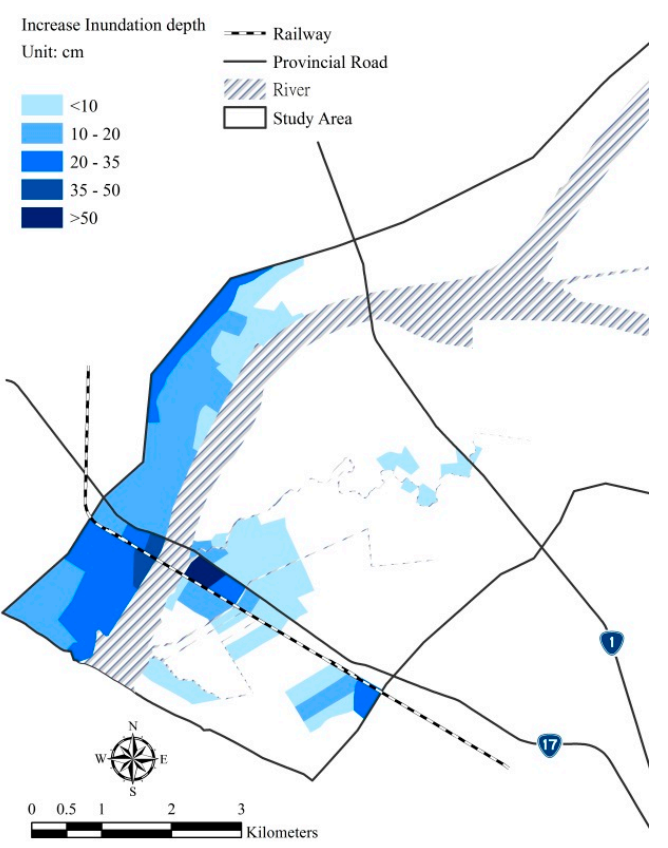

(a)

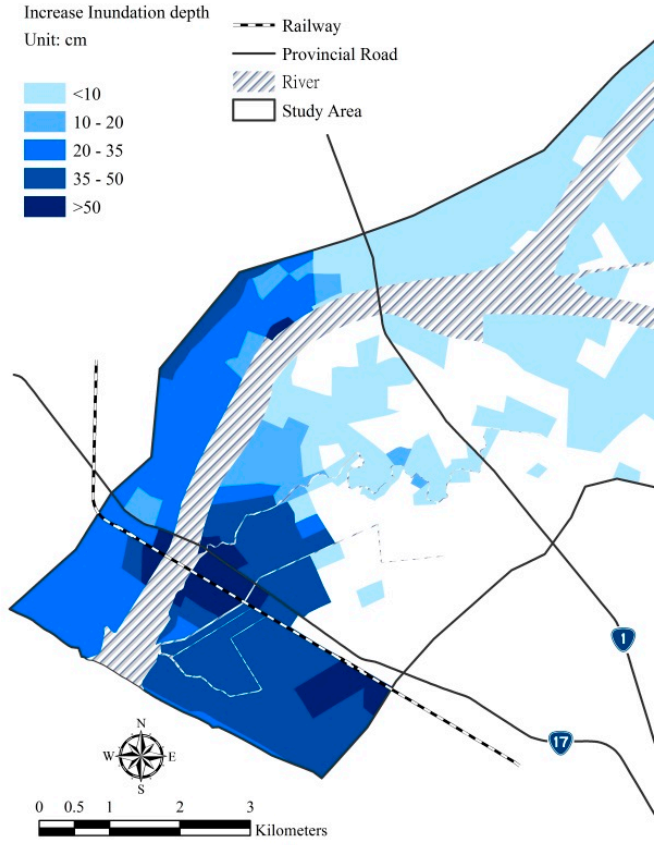

(b)

Figure 8. (a) Spatial distribution of inundation depth increase after land subsidence for a one-day storm under a 50-year return period; (b) Spatial distribution of inundation depth increase after land subsidence combined with climate change for a one-day storm under a 5-year return period.

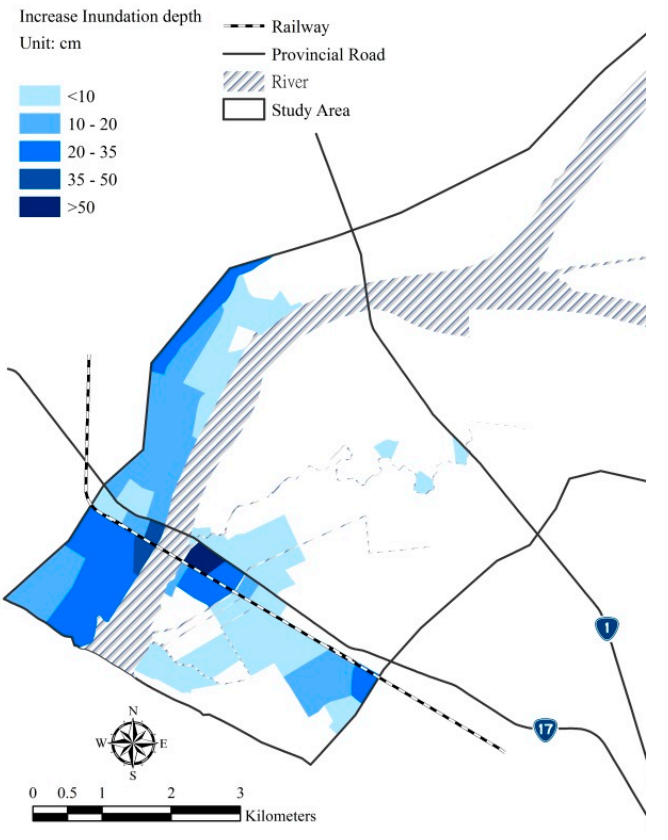

(a)

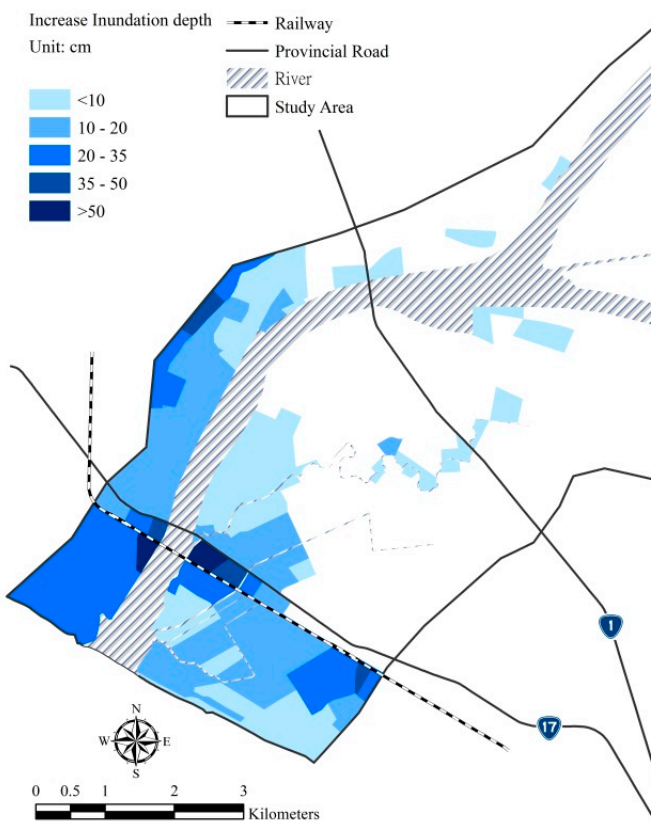

(b)

Figure 9. (a) Spatial distribution of inundation depth increase after land subsidence for a two-day storm under a 5-year return period; (b) Spatial distribution of inundation depth increase after land subsidence combined with climate change for a two-day storm under a 5-year return period. 


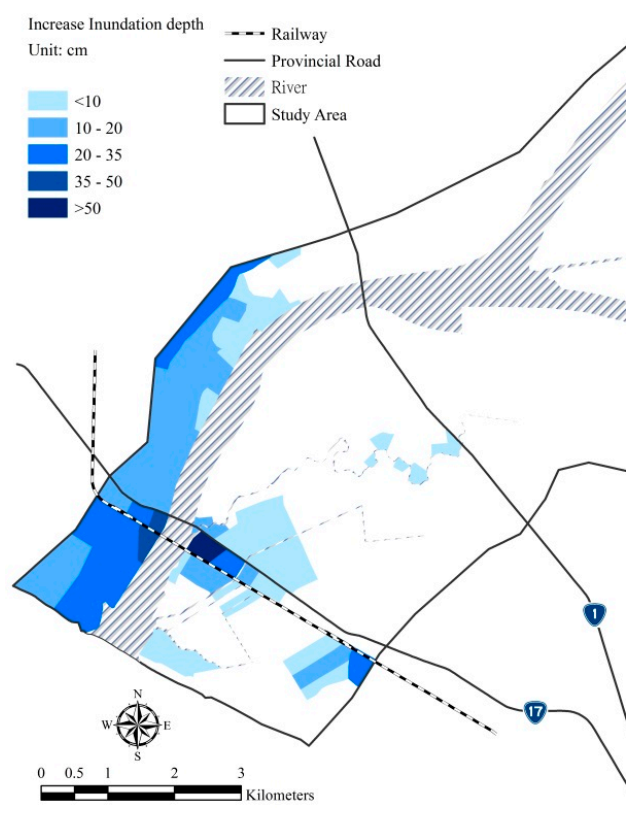

(a)

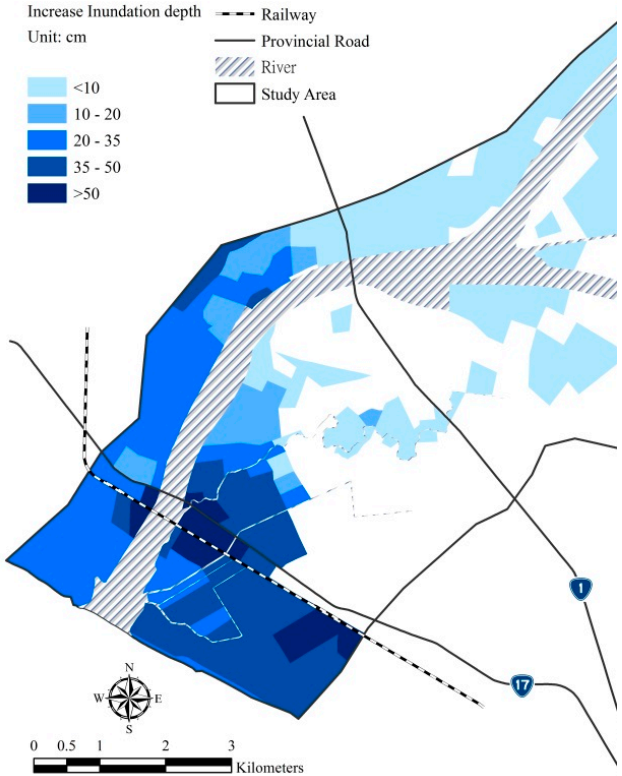

(b)

Figure 10. (a) Spatial distribution of inundation depth increase after land subsidence for a two-day storm under a 50-year return period; (b) Spatial distribution of inundation depth increase after land subsidence combined with climate change for a two-day storm under a 50-year return period.

Land subsidence does not only increase inundation depth but also weakens the functioning of existing drainage systems. To understand the influence of land subsidence and land subsidence combined with climate change on flooding duration, the average flooding duration of each computational cell in the land subsidence area (Provincial Highway No. 1 to river outlet boundary), alone and with the influence of climate change, for each return period, was calculated by the area-ratio-weighted average method. The average flooding duration $r_{a d}$ can be expressed as:

$$
\mathrm{r}_{a d}=\frac{\sum_{i=1}^{N}\left(r_{d} \times A_{s i}\right)}{\sum_{i=1}^{N} A_{s i}}
$$

The average inundation duration with one- and two-day storms for each return period are shown in Figures 11 and 12. These figures indicate that the average inundation duration after land subsidence for each return period tended to increase. Moreover, in the presence of land subsidence and the additional influence of climate change, the average inundation duration for each return period showed a significant increase, which was amplified as the return period increased. After land subsidence, the average inundation duration for each return period was 1.05-1.1 times greater than that before land subsidence. With the influence of both land subsidence and climate change, the average flooding duration for each return period was 1.13-1.27 times greater than that before land subsidence. Therefore, land subsidence tended to cause an increase in not only inundation depth but also in inundation duration. 


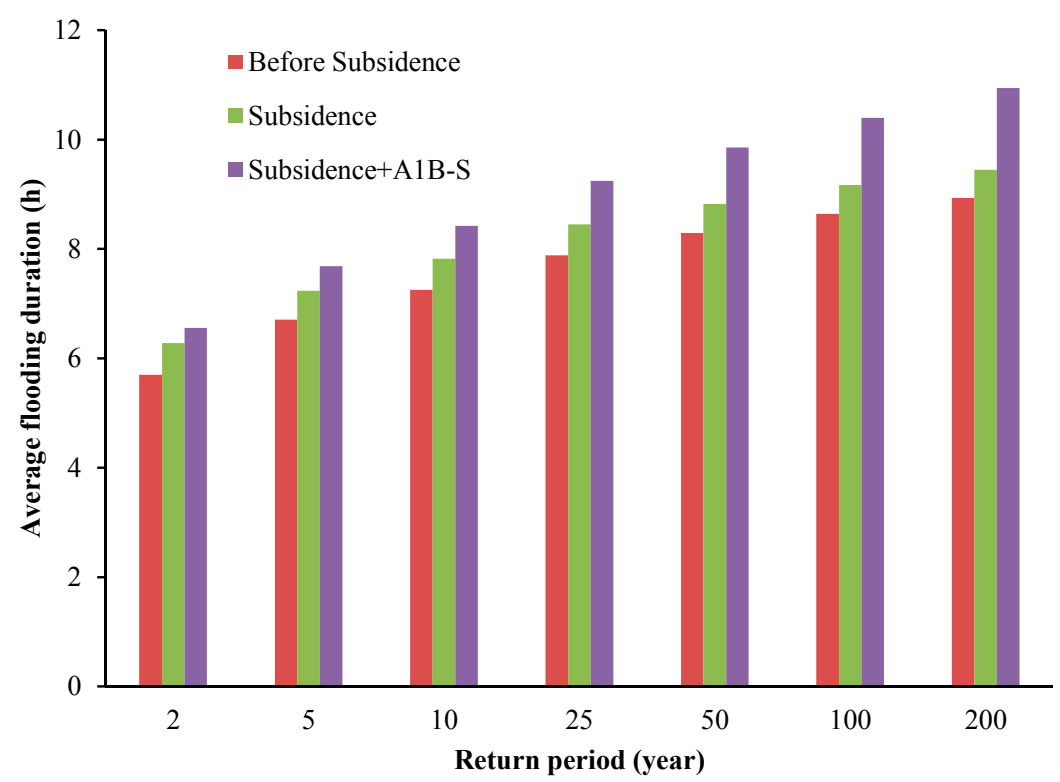

Figure 11. Average flooding duration for a one-day storm under different return periods and scenarios.

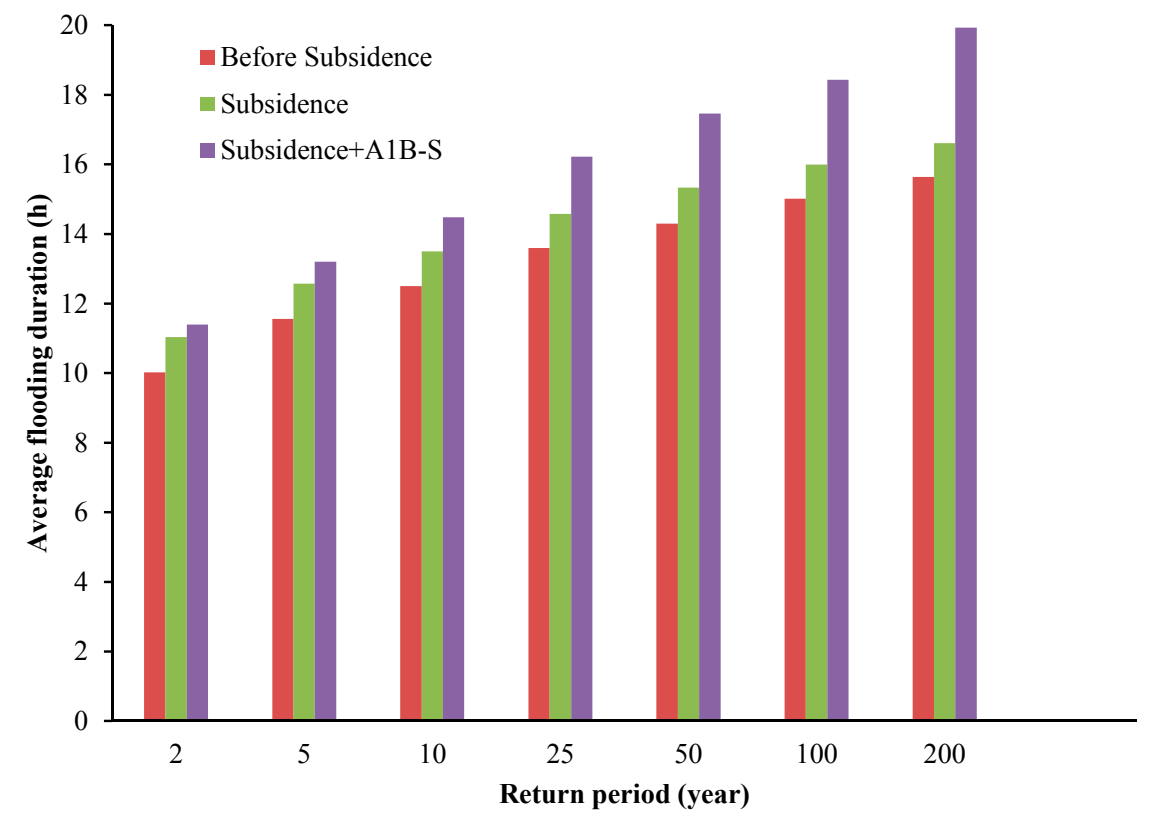

Figure 12. Average flooding duration for a two-day storm under different return periods and scenarios.

\subsection{Inundation Risk Analysis}

By applying inundation depth and duration derived from the inundation potential analysis and combining the land uses as well as the corresponding monetary value of the inundation area, the inundation loss index was assigned. This index can be used to calculate the inundation vulnerability for different return periods. Finally, inundation risk was determined. By subtracting the inundation risk before and after land subsidence, maps of the increase and distributions of inundation risk were prepared. The one- and two-day storms for the return periods of 5 years and 50 years were selected as examples, to demonstrate the influence of land subsidence on inundation risk, as shown in Figures 13 and 14. These figures show that locations such as the region between the railway and provincial road No. 17, as well as the boundary between the coastal bank and catchment area had higher increases 
in inundation risk since they were the most affected by land subsidence. Therefore, land subsidence worsens inundation hazard and disaster loss.

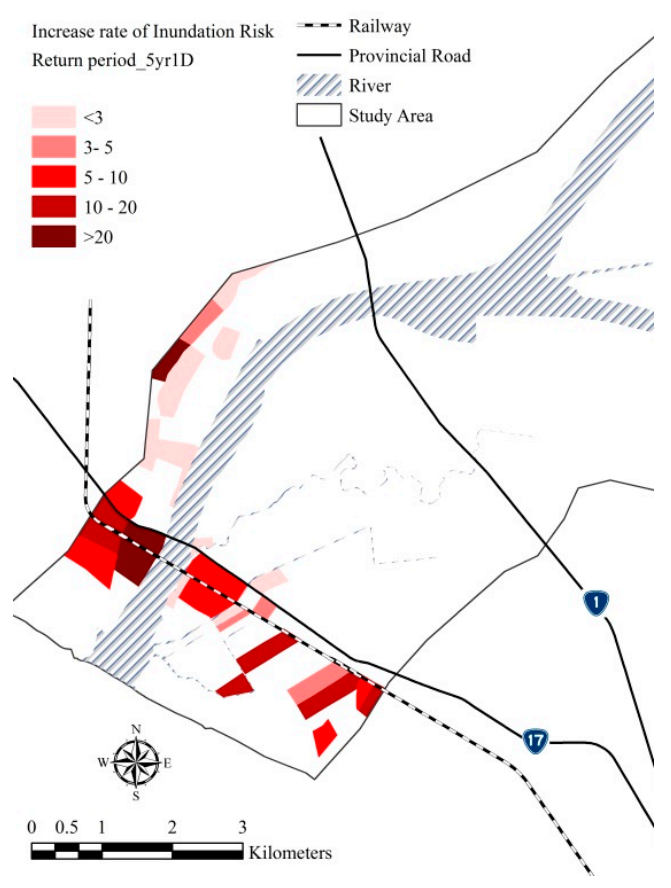

(a)

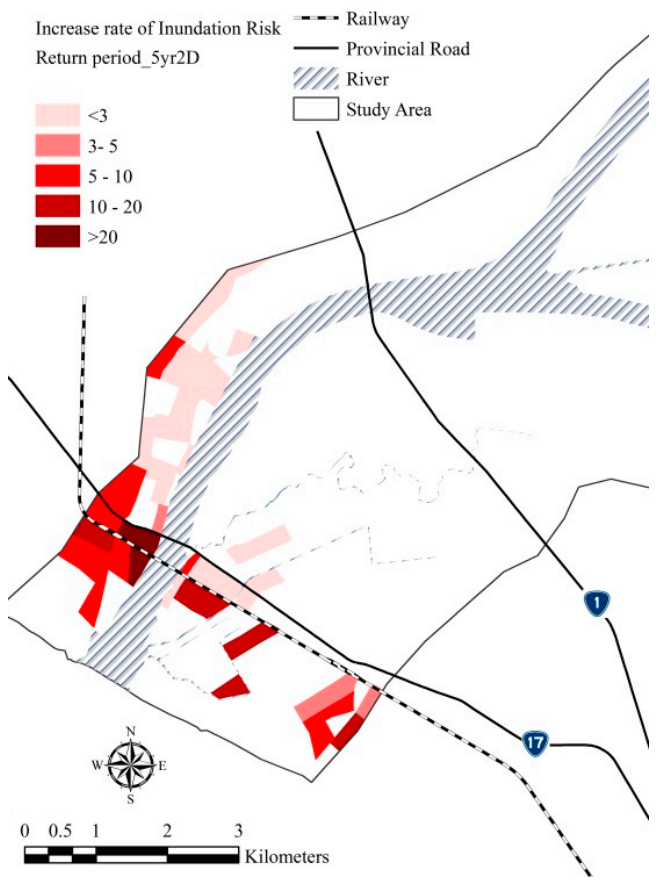

(b)

Figure 13. (a) Distribution map of inundation risk increase after land subsidence for a one-day storm under a 5-year return period; (b) Distribution map of inundation risk increase after land subsidence for a two-day storm under a 5-year return period.

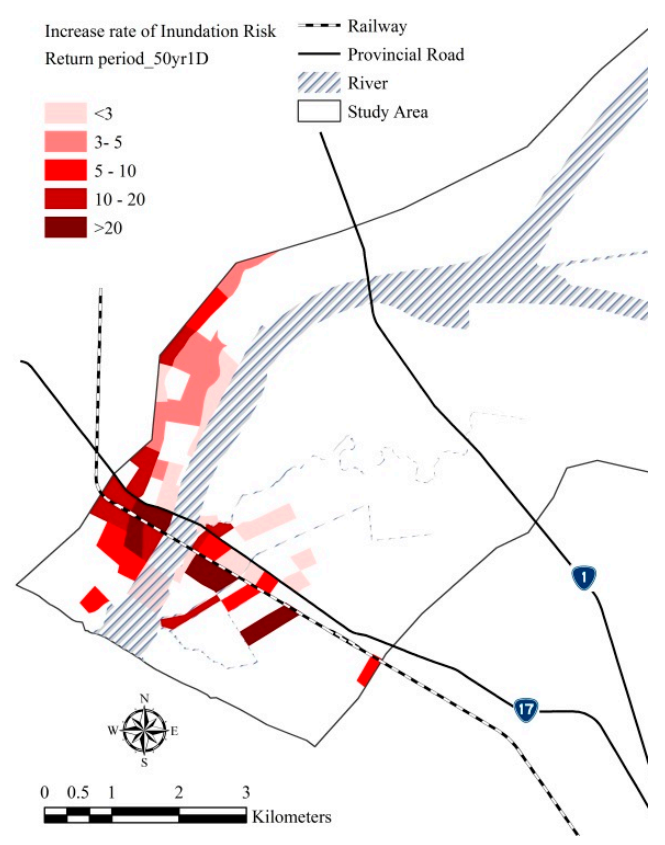

(a)

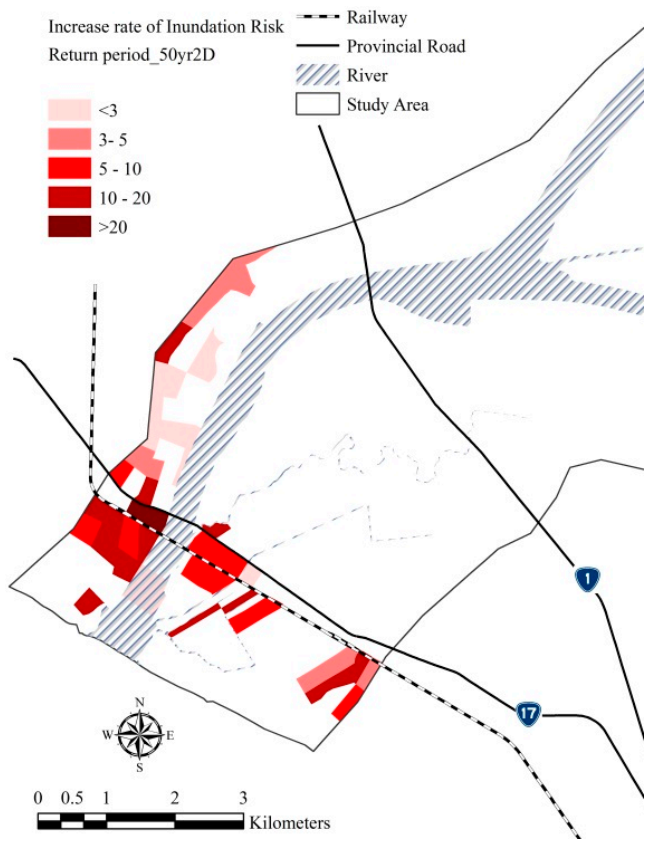

(b)

Figure 14. (a) Distribution map of inundation risk increase after land subsidence for a one-day storm under a 50-year return period; (b) Distribution map of inundation risk increase after $\mathbf{l}$ and subsidence for a two-day storm under a 50-year return period. 
Due to the influence of global climate change in recent years, abnormal weather conditions, such as extreme rainfall, have been observed more frequently in Taiwan. To understand the impacts of climate change and land subsidence on inundation risk in the study area, separate scenarios of inundation depth and duration for land subsidence with one- and two-day storms for each return period in the A1B-S scenario were simulated. By further applying the land use as well as the corresponding monetary value of the inundation area, the inundation loss index was assigned, which can be used to calculate the inundation vulnerability for different return periods and further determine the inundation risk. By subtracting the determined inundation risk of the A1B-S scenario from the current inundation risk, the increase and distribution maps of inundation risk were prepared. The one- and two-day storms for the return periods of 5 years and 50 years were selected as examples, to demonstrate the influence of climate change on inundation risk, as shown in Figures 15 and 16. These figures show that the inundation risk with one- and two-day storms under different return periods in the A1B-S scenario exhibited an increasing trend, and the increase in inundation risk was significantly higher than that with land subsidence alone. This implies that the inundation risk for the A1B-S scenario is higher than that of the existing condition, particularly for a storm with a larger return period.

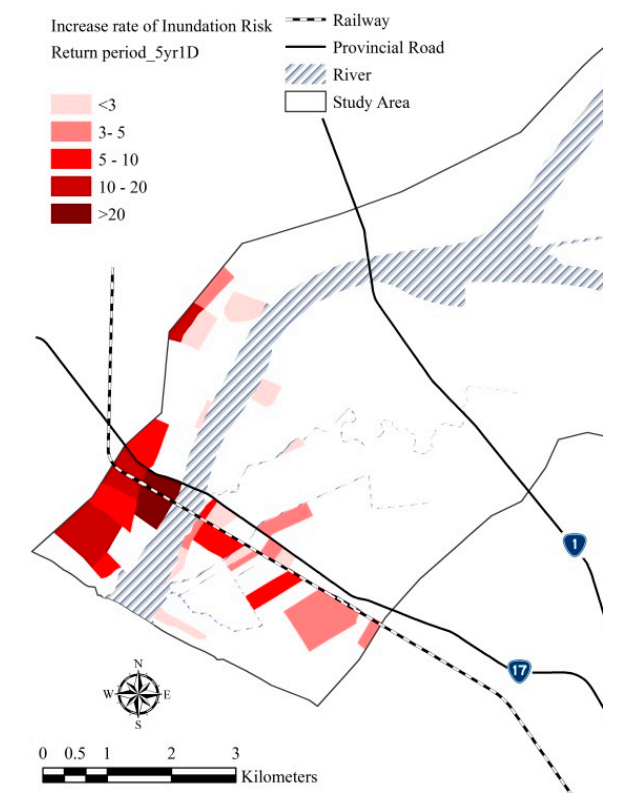

(a)

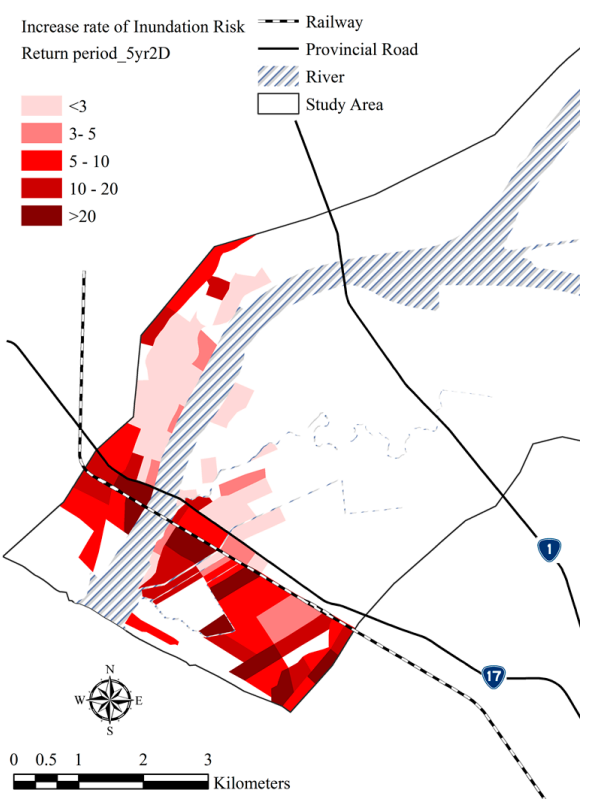

(b)

Figure 15. (a) Distribution map of inundation risk increase after land subsidence and A1B-S scenario for a one-day storm under a 5-year return period; (b) Distribution map of inundation risk increase after land subsidence and the A1B-S scenario for a two-day storm under a 5-year return period.

Applying the inundation depth and duration derived from the inundation potential analysis and combining the land uses and the corresponding production value of the inundation area, the inundation loss index was assigned. Subsequently, the inundation risk was determined. The average inundation risk $\left(R_{\text {avg }}\right)$ was calculated by the area-ratio-weighted average method, and can be expressed as:

$$
R_{\operatorname{avg}}(\%)=\frac{\sum_{i=1}^{N}\left(R_{i} \times A_{s i}\right)}{\sum_{i=1}^{N} A_{s i}}
$$

where $R_{i}$ represents the inundation risk in the $i$ cell and $R_{a v g}$ represents the average inundation risk. 


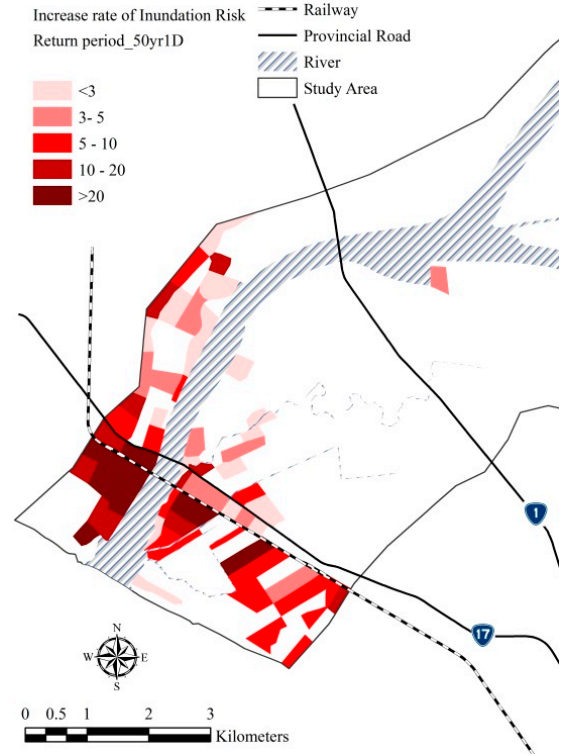

(a)

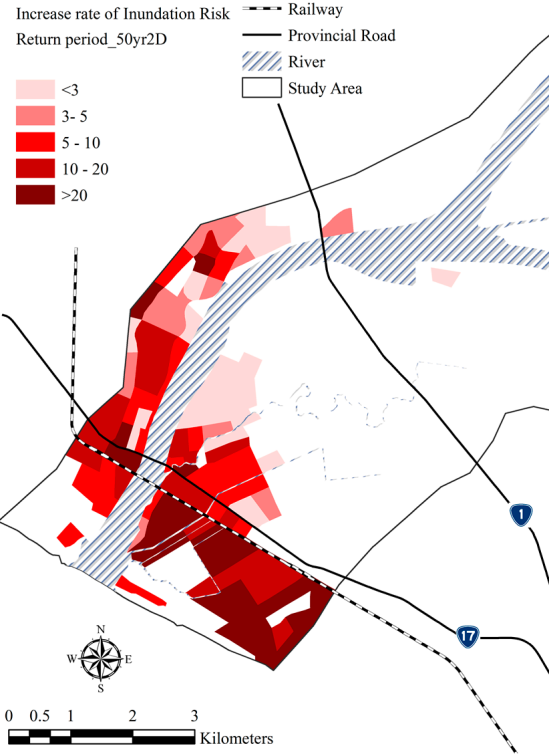

(b)

Figure 16. (a) Distribution map of inundation risk increase after land subsidence and A1B-S scenario for a one-day storm under a 50-year return period; (b) Distribution map of inundation risk increase after land subsidence and the A1B-S scenario for a two-day storm under a 50-year return period.

The risk value of each computational cell in the land subsidence area (Provincial Highway No. 1 to river outlet boundary) was multiplied by the area of the corresponding computational cell. The above-mentioned products for the entire land subsidence area were then accumulated and the sum was divided by the area of the land subsidence area to obtain the average risk value. This value was then used to derive the average inundation risk with one- and two-day storms for each return period. The inundation risks in the presence of land subsidence and land subsidence combined with climate change for each return period are shown in Figures 17 and 18. These figures show that the average inundation risk in the presence of land subsidence alone, or land subsidence combined with climate change with one- and two-day storms, for each return period, is higher than the inundation risk before land subsidence. Moreover, the average inundation risk of land subsidence combined with climate change is higher than that of land subsidence alone.

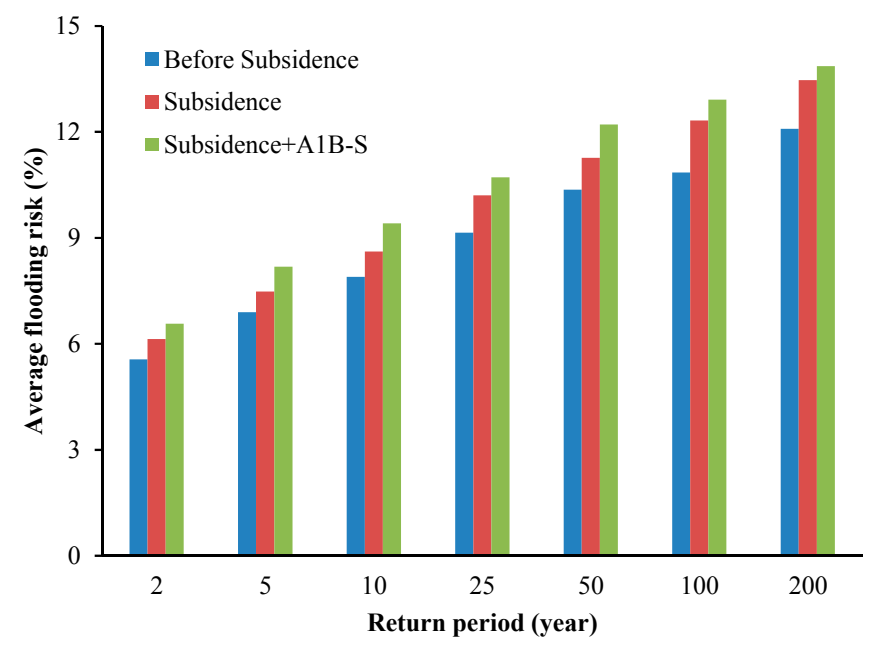

Figure 17. Average inundation risk for a one-day storm under different return periods and scenarios. 


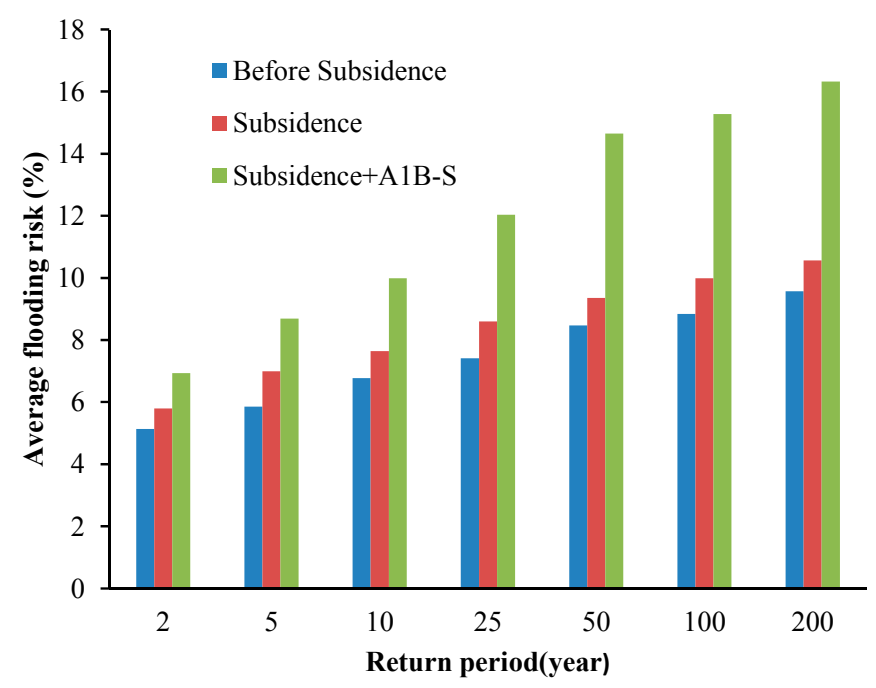

Figure 18. Average inundation risk for a two-day storm under different return periods and scenarios.

After land subsidence, the average inundation risk for each return period was 1.08-1.19 times greater than that before land subsidence. With the influence of both land subsidence and climate change, the average inundation risk for each return period was 1.14-1.73 times greater than that before land subsidence. Therefore, land subsidence combined with climate change seriously increases inundation risk, especially in any scenario with a two-day rainfall event.

\section{Conclusions}

An inundation risk evaluation model was developed using a PDI model, integrated with inundation depth, duration, and vulnerability. The inundation risk evaluation model analysed the impacts of land subsidence and the combination of land subsidence with climate change on inundation depth, area, volume, and inundation risk in a land subsidence-prone area. The PDI model could effectively simulate the inundation phenomenon after it was successfully validated by typhoon Morakot. The model was further applied to assess the effects of land subsidence and climate change on inundation disaster and risk. The results indicated that the inundation depth, area, and volume in the investigated area increased significantly after land subsidence; the inundation phenomenon was even worse when both land subsidence and climate change were present. Land subsidence increased not only inundation depth but also inundation duration. The average inundation duration for each return period after land subsidence was 1.05-1.1 times greater than that before land subsidence. With the influence of both land subsidence and climate change, the average inundation duration for each return period was 1.13-1.27 times greater than that before land subsidence. By further applying inundation depth and duration indices and combining the land uses as well as the corresponding monetary value of the inundation area, the inundation vulnerability index was assigned, which can be used to calculate the inundation risk for different return periods. The average inundation risk for each return period after land subsidence was 1.08-1.19 times greater than that before land subsidence. With the influence of both land subsidence and climate change, the average inundation risk for each return period was 1.15-1.73 times greater than that before land subsidence. Therefore, it is concluded that land subsidence and climate change significantly change the inundation potential and increase inundation depth, volume, and risk, making inundation disasters more severe.

Acknowledgments: This study was supported by grants from the Ministry of Science and Technology of Taiwan (MOST-103-2625-M-020-001 and MOST-104-2625-M-020-003). The authors gratefully acknowledge the support. Observed and hydraulic model test data for this study was provided by Data Bank for Atmospheric and Hydrologic Research of Taiwan Typhoon and Flood Research Institute (TTFRI), National Applied Research Laboratories (NARL), (https://dbahr.narlabs.org.tw/). The authors gratefully acknowledge their support. 
Author Contributions: Ching-Nuo Chen conceived the study, collected and analysed the data. Samkele S. Tfwala analysed the data and further wrote the manuscript.

Conflicts of Interest: The authors declare no conflict of interest.

\section{References}

1. Water Resources Agency. The Climate Change Knowledge Base on Water and the Environment; Ministry of Economic Affairs: Taichung, Taiwan, 2013; Volume 2016.

2. Wu, P.; Wood, R.; Ridley, J.; Lowe, J. Temporary Acceleration of the Hydrological Cycle in Response to a Co2 Rampdown. Geophys. Res. Lett. 2010, 37, 1-5. [CrossRef]

3. Intergovernmental Panel on Climate Change. Climate Change 2014: Synthesis Report; IPCC: Geneva, Switzerland, 2014; p. 151.

4. Liu, J.; Wang, H.; Yan, X. Risk evaluation of land subsidence and its application to metro safety operation in Shanghai. Proc. Int. Assoc. Hydrol. Sci. 2015, 372, 543-553. [CrossRef]

5. Tseng, Y.-H.; Breaker, L.C.; Chang, E.T.-Y. Sea level variations in the regional seas AROUND Taiwan. J. Oceanogr. 2010, 66, 27-39. [CrossRef]

6. Uitto, J.I. The geography of disaster vulnerability in megacities: A theoretical framework. Appl. Geogr. 1998, 18, 7-16. [CrossRef]

7. Hashimoto, T.; Stedinger, J.R.; Loucks, D.P. Reliability, resiliency, and vulnerability criteria for water resource system performance evaluation. Water Resour. Res. 1982, 18, 14-20. [CrossRef]

8. Hammer, W. Handbook of System and Product Safety; Prentice Hall: Upper Saddle River, NJ, USA, 1972.

9. Satu, K. Vulnerability concepts in hazard and risk assessment. Geol. Surv. Finl. 2006, 42, 65-74.

10. De Bruijn, K.M.; Klijn, F. Risky places in the Netherlands: A first approximation for floods. J. Flood Risk Manag. 2009, 2, 58-67. [CrossRef]

11. de Bruijn, K.; Buurman, J.; Mens, M.; Dahm, R.; Klijn, F. Resilience in practice: Five principles to enable societies to cope with extreme weather events. Environ. Sci. Policy 2017, 70, 21-30. [CrossRef]

12. Liu, S.C.; Fu, C.; Shiu, C.-J.; Chen, J.-P.; Wu, F. Temperature dependence of global precipitation extremes. Geophys. Res. Lett. 2009, 36, 1-4. [CrossRef]

13. Yang, C.J. Study on Construction of a Physiographic Inundation Forecasting System; National Cheng-Kung University: Tainan, Taiwan, 2000.

14. The Price Indices. Available online: https://www.dgbas.gov.tw/point.asp?index=2 (accessed on 1 October 2017).

15. The Sixth River Management Office. Regulation Planning for the Yenshui River; The Sixth River Management Office: Kaohsiung, Taiwan, 1998.

16. Water Resources Agency. Impact Assessment of Rainfall Variation under Different Climate Change Scenarios on Flood and Drought (I); Affairs, M.O.E., Ed.; Water Resources Agency: Taichung, Taiwan, 2015. 